\title{
Biogeochemistry of REE elements and tetrad effect in the soil-plant system: a study on volcanic rock covers in southernmost Brazil
}

\author{
MARIA DO CARMO LIMA E CUNHA ${ }^{1}$, LAURO V.S. NARDI ${ }^{1}$ and INGKE F. MULLER ${ }^{2}$ \\ ${ }^{1}$ Centro de Estudos em Geoquímica e Petrologia, Instituto de Geociências, \\ Universidade Federal do Rio Grande do Sul, Avenida Bento Gonçalves, 9500, 91509-900 Porto Alegre, RS, Brasil \\ ${ }^{2}$ Programa de Pós-Graduação em Geociências, Instituto de Geociências, \\ Universidade Federal do Rio Grande do Sul, Avenida Bento Gonçalves, 9500, 91509-900 Porto Alegre, RS, Brasil
}

Manuscript received on May 27, 2011; accepted for publication on August 11, 2011

\begin{abstract}
This paper deals with the distribution of REE in rock, soil and plant in an area of monzonitic rocks from southernmost Brazil. The REE patterns in Schinus lensticifolius show a negative-Ce anomaly and a prominent tetrad effect, characterized as W-type that are not present in rock and soil samples. The REE patterns in the soils and rocks sampled are very similar and there is no fractionation of REE during the processes of soil formation. The W-type patterns are interpreted as indicating that REE were absorved by S. lentiscifolius as simple ions rather than as complex ions, or, alternatively, that the transport of REE in the plant metabolic processes was as free ions. The recognition of tetrads, either, M- or W-type patterns, is an additional tool for understanding the biogeochemistry of REE and can contribute to the study of monitoring processes of contaminated environment or to mineral prospecting.
\end{abstract}

Key words: REE, tetrad effect, Schinus lentiscifolius, southernmost Brazil.

\section{INTRODUCTION}

The rare earth elements - REE - are concentrated mainly in accessory minerals of igneous or metamorphic rocks, and show low mobility in these high-temperature systems (Henderson 1984). Hydrothermal and weathering fluids, however, can mobilize the REE mainly by forming soluble complex ions (Nesbitt 1979, Topp et al. 1984, Lottermoser 1990). The concentration of REE in soils depends on the composition of source rocks, the weathering conditions, the organic matter content, among other factors, but in general the light REE (LREE) predominate over the heavy ones in the shallower layers, HREE (Tyler 2004). Plants under

Correspondence to: Maria do Carmo Lima e Cunha

E-mail: maria.cunha@ufrgs.br natural conditions absorb minimal amounts of REE (1 to $45 \mathrm{ppm}-\mathrm{wt} \%$ in ash) (Kabata-Pendias and Pendias 1984), although some species are capable of accumulating high levels of REE contents, in spite off their low solubility of REE in soil solutions (Milton et al.1944, Evans 1990, Osaki and Enomoto 2001, Tyler 2004). The REE are more soluble as chlorides, nitrates and perchlorates than in the form of carbonates, hydroxides and fluorides (Evans 1990). According to McLennan (1994) the chemical behavior of REE is controlled by their ionic radii, charge, volatility and stability of their complexes. A fifth factor named tetrad or double-double (Masuda and Ikeuchi 1979) is described by Mc Lennan (1994) as " a marked increase in stability represented by the half $(G d)$ and completely filled (Lu) 4 f electron shell 
and lesser but still significant increases in stability associated with the quarter (between $\mathrm{Nd}$ and Pm) and three-quarter filled (between $\mathrm{Ho}$ and Er) $4 f$ shell". McLennan (1994) considered that the tetrad effect is most apparent in natural waters or rocks that have interacted with fluids. Accordingly, sea water and material precipitated directly from sea water would possess "W-type" effects with four concave up segments to the REE pattern. Other materials displaying the tetrad effect due to interaction with water would possess "M-type" effects with four convex up segments in the REE pattern. Following Sastri et al. (2003), it is concluded that the tetrad effect reflects discontinuities in the third ionization potential of REE. Such discontinuities are also shown in the energy involved in the formation of complexes, so that, Nd-Pm, Gd, Ho-Er, and Lu demand more energy for forming complexes than their neighbors. That is the reason why they are depleted in relation to their neighbors (i.e. M-type pattern) in solutions where they are kept as complexes.

Fractionation of REE, including tetrad effects, has been reported by several authors (Fu et al.1998, Wyttenbach et al. 1998, Ding et al.2006, Ding et al. 2007, Lima e Cunha et al. 2010). However, mechanisms and controls of REE distribution and translocations in these systems, and in the vegetal structures are still poorly known. Further studies are needed, since the slight modifications in the REE capable of generating tetrad effects can affect their accumulation in plants, water and soils.

In this paper we discuss the distribution of REE in rock, soil and plant in an area of monzonitic rocks with copper-Au-sulphide mineralizations in order to contribute to the comprehension of REE geochemistry in the soil-plant system.

\section{MATERIALS AND METHODS}

The study area is situated nearby the city of Lavras do Sul, southernmost Brazil. The vegetation of the area consists of scrub forest in association with grass fields and thin lithosoils. The plant species selected for sampling, Schinus lentiscifolius (mastic), is a shrub about 2 or $3 \mathrm{~m}$ high with wide area distribution, easy recognition and high density, which simplifies the collection. The region of Lavras do Sul is dominated by volcanic and plutonic rocks which belong to the Lavras do Sul Shoshonitic Association (Nardi and Lima 1985), and the predominant lithologies in the study area are monzonites, quartz monzonites, rhyolites and latite dikes, (Liz et al. 2009).

Plant (10) and soil (5) samples were collected in places where some of these rocks have $\mathrm{Cu}-\mathrm{Au}$ sulphide mineralization (Fig. 1). In pre-processing, the selected organ (leaf) were washed with distilled water, dried at $80^{\circ} \mathrm{C}$ and calcined $\left(450^{\circ}-500^{\circ} \mathrm{C}\right)$ for a period of 6 to 8 hours (Brooks 1983), and the determination of the REE ( in ash) was carried out by ICP-MS. The detection limits (in ppm) are 0.002 for $\mathrm{La}, \mathrm{Pr}, \mathrm{Nd}$; 0.01 for $\mathrm{Ce}$; 0.001 for $\mathrm{Sm}, \mathrm{Eu}, 0.01$ for $\mathrm{Gd}$, and 0.001 for Tb, Dy, Ho, Er, Tm, Yb and Lu. The soil samples were dried, quartered and sieved and the fraction less than 200 mesh was separated by decanting. The resulting material $(0.5 \mathrm{~g})$ was subjected to fusion with a mixture of lithium metaborate - lithium tetraborate and analyzed by ICP - MS. The limits of detection for REE are the following: 0.05 for $\mathrm{La}, \mathrm{Ce}$ and $\mathrm{Nd} ; 0.01$ for Pr, Sm, Gd, Tb, Dy, Ho, Er and Yb, 0.005 for Tm and $\mathrm{Eu}, 0.02$ for $\mathrm{Lu}$.

The analytical procedures for all samples were performed by Act Labs, Canada. The REE patterns in figures $2 \mathrm{a}, 2 \mathrm{~b}$ and $2 \mathrm{c}$, were calculated based on C1 chondritic values after Evensen et al. (1978).

\section{RESULTS}

The REE chondrite-normalized patterns are broadly similar in rock (Fig. 2c), soil (Fig. 2b) and plant samples (Fig. 2a), although the contents in plant samples are about ten times lower than in soils and rocks. The contents of REE and some of their representative parameters in soils, rocks and plants are in Tables I and II, respectively. 


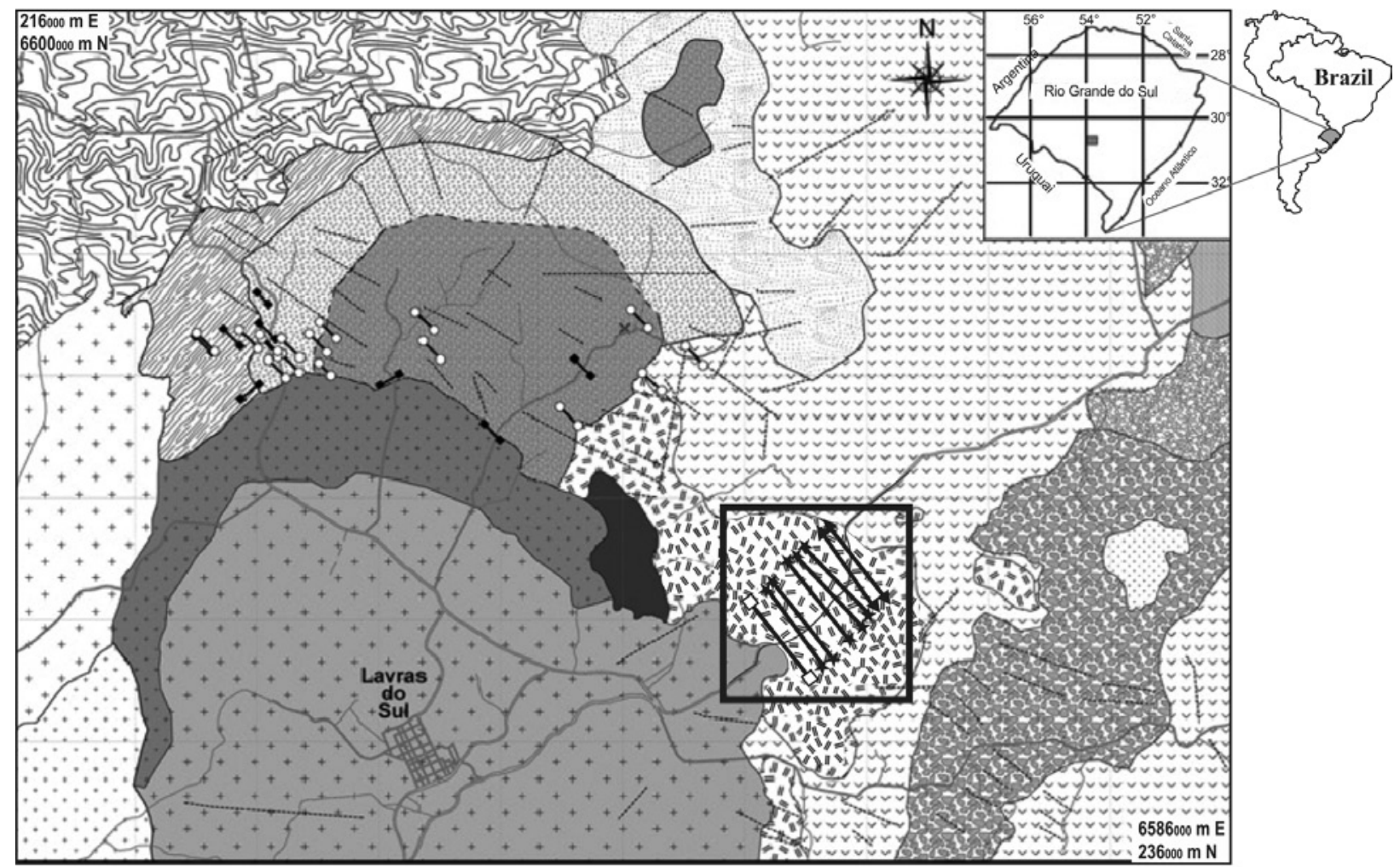

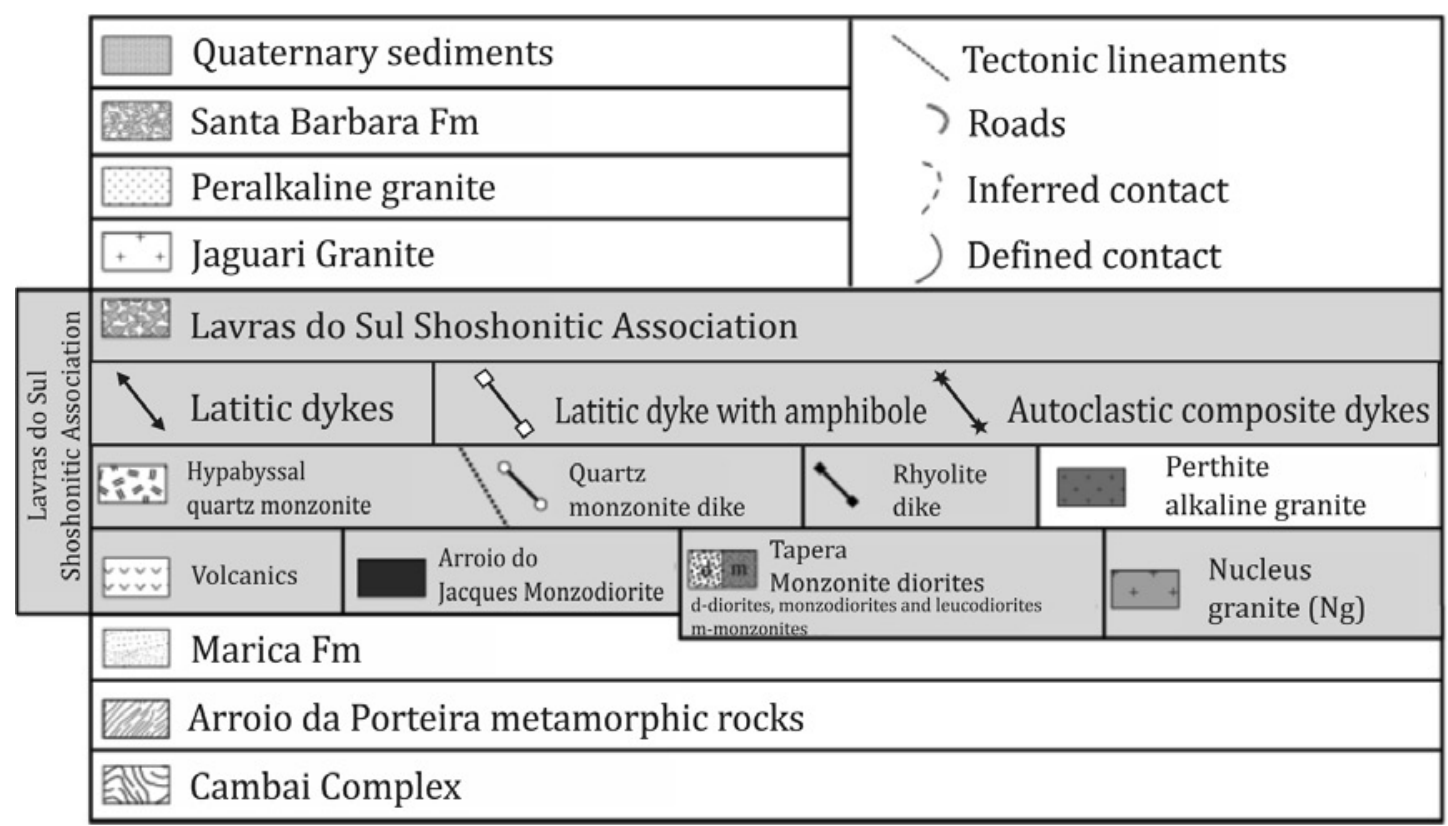

Figure 1 - Geological map with outline of the area modified from Liz et al. (2009). The square highlights the area where samples were collected along the road. The letters represent the lithologies of the Lavras do Sul Shoshonitic Association - ASLS. Maj - Arroio dos Jaques Monzonite; Mh - Hypabyssal Monzonites, V - Volcanic rocks; Ng - Lavras do Sul Granite Cv - Volcanic Conglomerate. 
TABLE I

REE concentrations in ash leaves of Schinus lentiscifolius. Values in ppm.

\begin{tabular}{c|cccccccccc}
\hline Sample & DK 01 & DK 02 & DK 03 & DK 04 & DK 05 & DK 06 & DK 07 & DK 08 & DK 09 & DK 10 \\
\hline $\mathrm{La}$ & 12.2 & 13.8 & 6.32 & 8.72 & 4.58 & 2.83 & 2.34 & 2.74 & 5.22 & 4.26 \\
$\mathrm{Ce}$ & 7.09 & 11.5 & 4.7 & 6.99 & 4.5 & 2.19 & 1.25 & 1.34 & 2.68 & 1.84 \\
$\mathrm{PR}$ & 1.44 & 2.45 & 0.928 & 1.93 & 0.56 & 0.411 & 0.233 & 0.256 & 0.512 & 0.522 \\
$\mathrm{Nd}$ & 4.76 & 8.75 & 3.19 & 8.04 & 1.99 & 1.49 & 0.756 & 0.826 & 1.55 & 1.81 \\
$\mathrm{Sm}$ & 0.722 & 1.32 & 0.518 & 1.32 & 0.285 & 0.207 & 0.101 & 0.105 & 0.192 & 0.225 \\
$\mathrm{Eu}$ & 0.056 & 0.191 & 0.11 & 0.289 & 0.076 & 0.047 & 0.041 & 0.047 & 0.055 & 0.053 \\
$\mathrm{Gd}$ & 0.69 & 1.33 & 0.56 & 1.3 & 0.29 & 0.2 & 0.1 & 0.11 & 0.2 & 0.22 \\
$\mathrm{~Tb}$ & 0.063 & 0.133 & 0.057 & 0.134 & 0.027 & 0.019 & 0.01 & 0.01 & 0.016 & 0.019 \\
$\mathrm{Dy}$ & 0.212 & 0.521 & 0.232 & 0.556 & 0.094 & 0.076 & 0.038 & 0.037 & 0.057 & 0.065 \\
$\mathrm{Ho}$ & 0.034 & 0.09 & 0.043 & 0.102 & 0.016 & 0.013 & 0.007 & 0.007 & 0.01 & 0.013 \\
$\mathrm{Er}$ & 0.082 & 0.222 & 0.106 & 0.265 & 0.045 & 0.036 & 0.02 & 0.018 & 0.028 & 0.032 \\
$\mathrm{Tm}$ & 0.007 & 0.021 & 0.011 & 0.025 & 0.005 & 0.004 & 0.003 & 0.003 & 0.003 & 0.003 \\
$\mathrm{Yb}$ & 0.04 & 0.102 & 0.059 & 0.124 & 0.036 & 0.022 & 0.023 & 0.024 & 0.02 & 0.022 \\
$\mathrm{Lu}$ & 0.007 & 0.015 & 0.01 & 0.019 & 0.009 & 0.004 & 0.006 & 0.006 & 0.005 & 0.005 \\
\hline
\end{tabular}

TABLE II

Average contents of REE in plant (Schinus lentiscifolius), soil and rock samples.

\begin{tabular}{lc|c|c}
\hline Plant & & Soil & Rock \\
\hline$\sum$ REE & 16.46 & 237.39 & 259.60 \\
$\sum$ LREE (La-Eu) & 15.54 & 221.20 & 245.00 \\
$\sum$ HREE (Gd-Lu) & 0.92 & 16.19 & 14.60 \\
LREE/HREE & 20.69 & 13.66 & 17.50 \\
LaN/YbN & 90.10 & 21.24 & 26.34 \\
\hline
\end{tabular}

REE patterns in plants show negative-Ce anomalies that are not present in rock and soil samples. The intensity of $\mathrm{Ce}$ anomalies is represented by: the $\mathrm{Ce}$ content determined, divided by the Ce estimated $\left(\mathrm{Ce}^{*}\right)$ from the average of their neighbors ( $\mathrm{La}$ and $\mathrm{Pr}$ ), considering the normalized values. In the plant samples the $\mathrm{Ce} / \mathrm{Ce}^{*}$ ratio varies from 0.25 to 0.58 , indicating clear negative anomalies in all samples.

The other important feature that is recognized only in plant patterns is the prominent tetrad effect characterized as W-type due to the concave- up pattern segments (Fig. 2a). The intensity of the tetrad effect was measured in the graphics, as suggested by Irber (1999): values of T1 (La-Ce-Pr-Nd), T3 (GdTr-Dy-Ho) and T4 (Er-Tm-Yb-Lu) significantly larger than 1 indicates that the M-type pattern occurs, while values significantly lower than 1 indicate the W-type effect. T2 value is difficult to be calculated because of Eu variable behavior. T1, T3, and T4 values for plant samples in the studied area are respectively $0.87,0.82,0.80$; and the $\mathrm{T} 1,3$ value, which represents the average of $\mathrm{T} 1$ and $\mathrm{T} 3$ is 0.84 .

REE patterns in the soils and rocks sampled are very similar (Fig. $2 b$ and $2 c$ ), and, there is no fractionation of REE during the processes of soil formation. These patterns are typical of rocks of shoshonitic affinity as described previously by Lima and Nardi (1998) and Liz et al. (2009).

\section{DISCUSSION}

The REE patterns of the Schinus lentiscifolius show clear differences from those of soils and rocks in the 

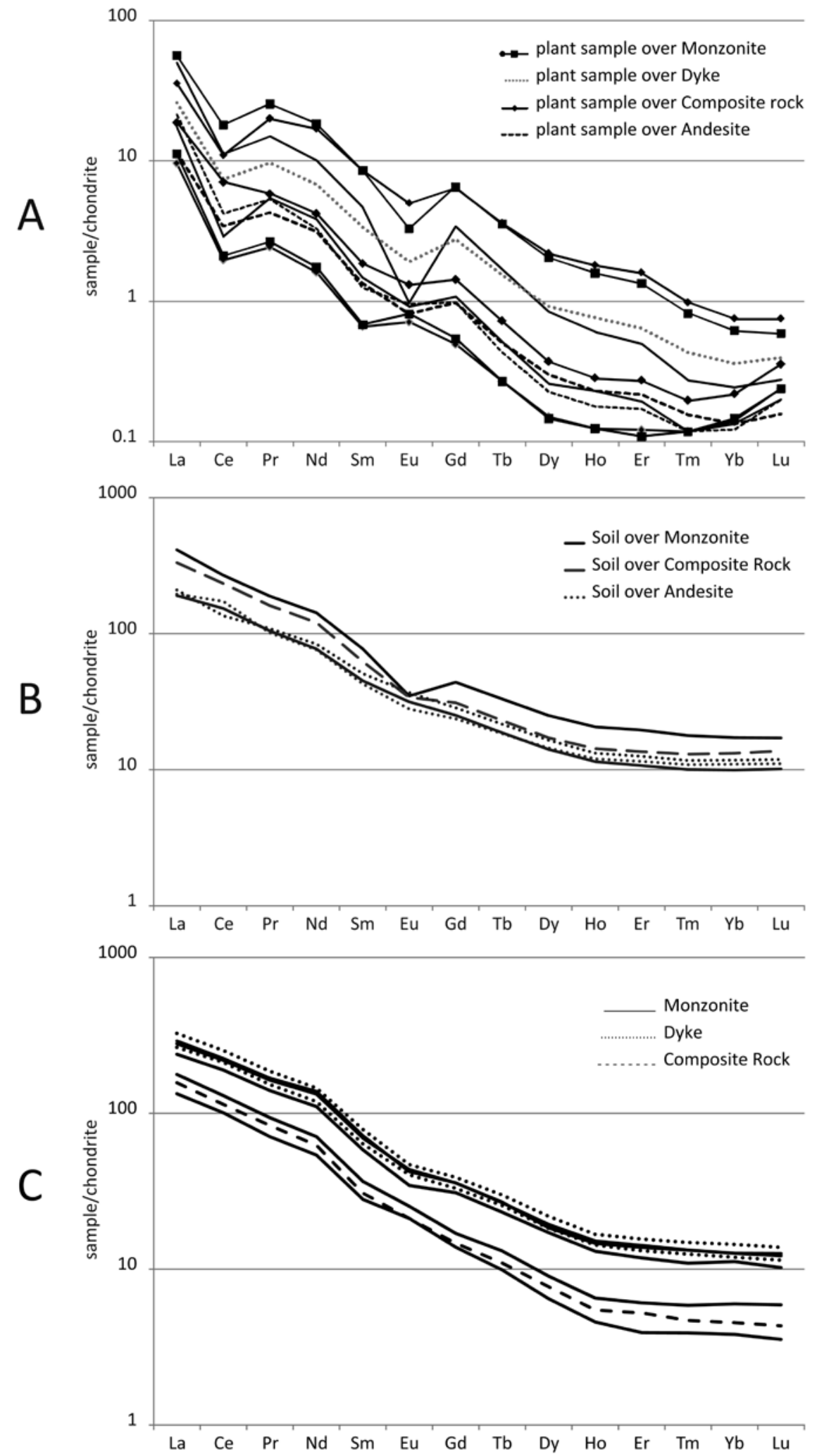

Figure 2 - Chondrite normalized REE patterns in (a) leaves of Schinus lentiscifolius, (b) soils, and (c) rocks from Lavras do Sul Shoshonitic Association (ASLS). 
study area: they have (i) distinct Ce-negative anomalies, the (ii) HREE to LREE fractionation is higher, and (iii) plant patterns show W-type tetrad effects.

According to Evans (1990) the REE are insoluble in the form of carbonates, hydroxides, phosphates and fluorides. Shan et al. (2002) observed that the sorption of REE increase when the concentration of organic acids around the plant roots is higher. Wyttenbach et al. (1998) found Ce/ $\mathrm{Ce}^{*}$ ratio $\left(\mathrm{Ce}^{*}=\right.$ average of $\mathrm{La}$ and $\mathrm{Pr}$ contents $)$ values ranging from 0.28 for ivy to 0.67 for fern, and concluded that $\mathrm{Ce}$ anomalies of the plant species are always lower than 1 . They considered that small changes of the redox potential of the rhizosphere might have contributed to the increase of this variability. The negative anomalies probably reflect the oxidation of trivalent to tetravalent $\mathrm{Ce}$, which causes the decrease of its mobility in the rhizosphere (Fu et al. 1998), and its consequent decrease of solubility in relation to other REE.

The preferential concentration of LREE by plants has been observed by several authors. Miao et al. (2007) observed that the fractionation of HREE in relation to LREE occurs during transport in the soilplant system. According to these authors, organic acids of low-molecular weight are dominant in solubilizing LREE, so they increase their availability and consequent absorption by plants. Zhang et al.
(2002) proposed that fractionation does not occur during the absorption of REE in the rhizosphere, but during transport and deposition of REE in the vegetal tissues. Wang et al. (1997) and Ding et al. (2006) suggest that REE fractionation occurs either, in the rhizosphere or in the plant tissues, by reacting with organic ligands. A comparison of REE contents in plant and soil samples (Fig. 3) shows that LREE and MREE are more enriched than HREE in plants. Cerium is less mobilized to the plant than other LREE. Lutecium and Gd can show slight positive anomalies that can be ascribed to the tetrad effect of W-type. Europium shows a variable behavior with positive or negative anomalies that can be explained by the oxidation $(\mathrm{Eu}+++$ versus $\mathrm{Eu}++)$ in the soil/plant system.

The tetrad effect W-type observed in the plant samples reflects the higher absorption of those REE that demand more energy for forming complexes, as discussed by Sastri et al. (2003). Fu et al. (1998) proposed that the tetrad effect in plants is controlled by the form of REE ions in the absorbed solutions; therefore, it depends on the occurrence of them as organic complexes or free cations. Solutions where complexes of REE are predominant in relation to free cations will precipitate compounds with M-type patterns; when free cations are dominant, $\mathrm{W}$-type patterns will be produced. Hence, according to those authors, the

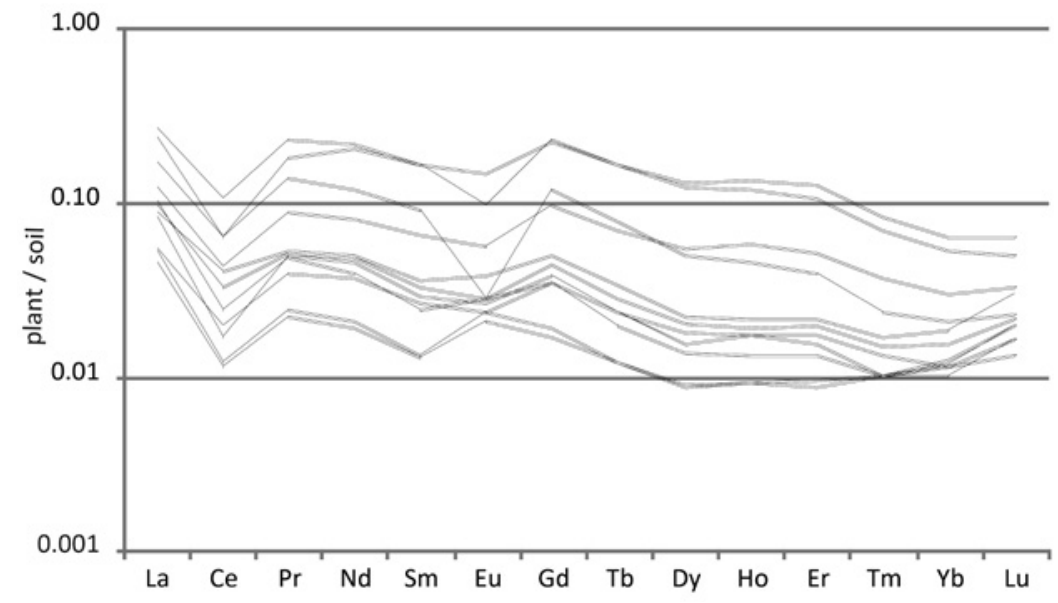

Figure 3 - REE patterns of plants normalized against the average contents in soils. 
W-type patterns indicate that the REE where absorbed by the plant dominantly as free cations. As additional evidence, $\mathrm{Fu}$ et al. (1998) explain the negative Ce anomalies by its oxidation in the soil/plant system to tetravalent $\mathrm{Ce}$, a more insoluble form that would be less absorbed by the plant.

Kovalevskii (1979) determined that the absorption of chemical elements by plants in the soil/plant system is 3,000 times higher as soluble forms than as solid phases. The W-type tetrad effect observed in the S. lentiscifolius in the Lavras do Sul area indicates that the soluble forms are free ions as proposed by Fu et al. (1998) for ferns.

\section{CONCLUSIONS}

There are some general similarities in rocks, soils and plants in the Lavras do Sul area such as an approximate parallelism of chondrite-normalized REE patterns. The patterns determined in S. lentiscifolius samples when compared to those of soils show, however, relevant differences: LREE enrichment, negative Ce anomalies, variable behavior of $\mathrm{Eu}$, and, particularly the development of W-type patterns, resulting in a tetrad effect. The W-type patterns are interpreted as indicating that REE were absorbed by $S$. lentiscifolius as simple ions rather than as complex ions or, alternatively, that the transport of REE in the plant metabolic processes was as free ions. $\mathrm{Ce}$ and $\mathrm{Eu}$ anomalies are caused by oxidation of these elements to tetra and trivalent forms, respectively, which reduces their mobility in the soil/plant system, and, consequently the $\mathrm{Ce}$ and $\mathrm{Eu}$ availability to plants. The $\mathrm{Gd}$ and $\mathrm{Lu}$ positive anomalies were observed in other plant species by other authors (Semhi et al. 2009, Lima e Cunha et al. 2009) and can be explained by the tetrad effect of $\mathrm{W}$-type, as previously proposed by $\mathrm{Fu}$ et al. $(1998,2000)$ and Lima e Cunha et al. (2010). W-type patterns such as those described in this paper have been referred mainly in sea-water and minerals deposited from hydrothermal solutions. The recognition of tetrads, either, M- or W-type patterns, is an additional tool for understanding the biogeochemistry of REE and can contribute to the study of monitoring processes of contaminated environment or to mineral prospecting.

\section{RESUMO}

Este trabalho trata da distribuição dos ETR na rocha, solo e planta em área de ocorrência de rochas monzoníticas do extremo sul do Brasil. O padrão dos ETR em Schinus lentiscifolius apresenta anomalia negativa de Ce e significativo efeito tétrade, do tipo $\mathrm{W}$, ausente no padrão da rocha e do solo. A configuração das curvas da rocha e do solo é similar e sem fracionamento das ETR durante a pedogênese. $\mathrm{O}$ padrão em $\mathrm{W}$ é interpretado como decorrente da absorção dos ETR pela planta na forma de íons livres e não complexados, ou, alternativamente, que o transporte das ETR nos processos metabólicos foi na forma de íons livres. O reconhecimento de tétrades, seja do tipo W ou M, é uma ferramenta adicional na compreensão da biogeoquímica dos ETR e pode contribuir para o estudo de processos de monitoramento de ambientes contaminados ou para pesquisas em prospecção mineral.

Palavras-chave: ETR, efeito tétrade, Schinus lentiscifolius, sul do Brasil.

\section{REFERENCES}

BROOKS RR. 1983. Biological Methods of Prospecting for Minerals. J Wiley \& Sons, New York, 322 p.

Ding S, Liang T, Chaosheng Z, Zechun H, YAning X AND TONGBIN C. 2006. Fractionation Mechanisms of Rare Earth Elements (REEs) in Hydroponic Wheat: An Application for Metal Accumulation by Plants. Environ Sci Technol 40: 2696-2691.

Ding S, Liang T, Yan JC, Zhang Z, HuAng ZC And Xie YN. 2007. Fractionations of rare earth elements in plants and their conceptive model. Sci Chine Serie C: Life Science 50(1): 47-55.

Evans CH. 1990. Biochemistry of Lanthanides. Pergamon Press 8: 444.

EVENSEN NM, HAMILTON PJ AND O'NIONS RK. 1978. Rareearth abundances in chondritic meteorites. Geochim Cosmochin Acta 42: 1099-1112.

Fu F-F, AKAGI TAND SHINOTSUKAK. 1998. Distribution Pattern of Rare Earth Elements in Fern. Implication for Intake of Fresh Silicate Particles by Plants. Biol Trace Elemt Res 64: 1-14. 
Fu F-F, AKAGI T, YABUKI S AND IwAKI M. 2000. Distributions of Rare Earth Elements in Seaweed: Implication of two different sources of Rare Earth Elements and Silicon in Seaweed. J Phycol 36: 62-70.

HENDERSON P. 1984. Rare Earth Elements Geochemistry. Developments in Geochemistry. Elsevier, Amsterdam 2: 510.

IRBER W. 1999. The lanthanide tetrad effect and itscorrelation with $\mathrm{K} / \mathrm{Rb}, \mathrm{Eu} / \mathrm{Eu}^{*}, \mathrm{Sr} / \mathrm{Eu}, \mathrm{Y} / \mathrm{Ho}$ and $\mathrm{Zr} / \mathrm{Hf}$ of evolving peraluminous granite suits. Geochim Cosmochim Acta 63: 489-508.

Kabata-Pendias A And Pendias H. 1984. Trace Elements in Soils and Plants. CRC Press, Florida, 315 p.

KovaleVsKII AL. 1979. Biogeochemical Exploration for Mineral Deposits. Oxonian Press, New Delhi, 136 p.

Lima E CUNHA MC, NARDI LVS AND Formoso MLL. 2010. Absorção e fracionamento dos elementos Terras Raras por vegetais: Estudo comparativo em plantas ocorrentes em diferentes contextos litológicos. Geologia Ser Cient USP 10(1): 53-59.

Lima e Cunha MC, Pereira VP, Bastos Neto AC, Nardi LVS, Formoso MLL AND MENEGOTTO E. 2009. Biogeoquímica dos elementos terras raras na Província Estanífera de Pitinga (AM). Rev Bras Geoc 9(3): 560-566.

LIMA EF AND NARDI LVS. 1998. The Lavras do Sul Shoshonitic Association: implications for the origin and evolution of Neoproterozoic shoshonitic magmatism in southernmost Brazil. J South Am Earth Sci 11(1): 67-77.

Liz JD, Lima EF, NARdi LVS, SOMMER CA, SALDANHA DL AND PIEROSAN R. 2009. Petrologia e sucessão estratigráfca das rochas monzoníticas da associação shoshonítica de Lavras do Sul (RS). Rev Bras Geoc 39(2): 244-255.

LOTTERMOSER BG. 1990. Rare earth elements mineralization within the Mt Weld carbonate laterite, Western Australia. Lithos 24: 151-167.

MASUDA A AND LKEUCHI Y. 1979. Lanthanide tetrad effect observed in marine environment. Geochem J 13: 19-22.

MCLENNAN MS. 1994. Rare earth element geochemistry and the "tetrad" effect. Geochim Cosmochim Acta 58: 2025-2033.

MiaO L, XU R AND XU J. 2007. Geochemical characteristics of rare earth elements (REEs) in the soil-plant system in West Guangdong Province, Acta Pedol Sinica 44(1): 54-62.
Milton MC, Murata KJ AND KnEtchel MK. 1944. Weinschenkite, yttrium, phosphate dihydrate from Virginia. Am Mineral 29: 92-107.

NARDI LSV AND LIMA EF. 1985. A associação shoshoníticade Lavras do Sul, RS. Rev Bras Geoc 15(2): 139-146.

NESBITT HW. 1979. Mobility and fractionation of rare earth elements during the weathering of a granodiorite. Nature 279: 206-210.

OZAKI T AND ENOMOTO S. 2001. Uptake of rare earth elements by Dryopteris erythrosora (autumn fern). RIKEN Rev 35: Focused on New Trends in Bio-Trace Elements Research, p. 84-87.

Sastri VS, BÜNZli JC, Perumareddi JR, Rao VR AND RAYUDU GVS. 2003. Modern Aspects of Rare Earths and Their Complexes. Elsevier, Amsterdam, 764 p.

Semhi T, Chaudhuri S AND Clauer N. 2009. Fractionation of rare-earth elements in plants during experimental growth in varied clay substrates. App Geochem 24: 447-453.

SHAN X-Q, LIAN J AND WEN B. 2002. Effects of organic acids on adsorption and desorption of Rare Earth Elements. Chemosphere 47: 701-710.

Topp SE, Salbu B, Roaldset E AND Jorgensen P. 1984. Vertical distribution of trace elements in laterite soil (Suriname). Chem Geol 47(1/2): 159-174.

TYLER G. 2004. Rare earth elements in soil and plant systems A review. Plant and Soil: 267 (1/2): 191-206.

WANG YQ, Sun J, CHEN HMF AND GuO Q. 1997. Determination of the contents and distribution characteristics of REE in natural plants by NAA. J. Radioanal Nucl Chem 219 (1): 99-103.

WytTENBACH A, FURRER V, SCHLEPPI P AND TOBLER L. 1998 Rare earth elements in soil and in soil-grown plants. Plant and Soil 199: 267-273.

ZhaNG ZY, WANG YQ, Li FL, XiAO HQ AND Chai ZF. 2002. Distribution characteristics of rare earth elements in plants from a rare earth ore area. J Radioanal Nucl Chem 252(3): 461-465. 